RIBEIRO, JRS; BEZERRA NETO, F; LIMA, JSS; CHAVES, AP; SILVA, JN; SANTOS, EC; NUNES, RLC. 2020. Production efficiency in cultivar combinations of beet and cowpea. Horticultura Brasileira 38: 445-453. DOI: http://dx.doi.org/10.1590/s0102-0536202004017

\title{
Production efficiency in cultivar combinations of beet and cowpea
}

\author{
Jeisy RS Ribeiro ${ }^{1 \mathbb{D}}$; Francisco Bezerra Neto ${ }^{1} \mathbb{D}$; Jailma SS Lima ${ }^{1} \mathbb{D}$; Aridênia P Chaves ${ }^{1} \mathbb{D}$; Josimar N \\ Silva ${ }^{2} \mathbb{D}$; Elizangela $C$ Santos ${ }^{1} \mathbb{D}$; Renato LC Nunes ${ }^{3} \mathbb{D}$
}

${ }^{1}$ Universidade Federal Rural do Semi-Árido (UFERSA) Mossoró-RN, Brasil; jeisyribeiro@hotmail.com; ${ }^{2}$ Secretaria de Agricultura de Belém do Brejo do Cruz, Belém do Brejo do Cruz-PB, Brasil; josimar2160@hotmail.com; ${ }^{3}$ Instituto Federal do Ceará (IFCE), Limoeiro do Norte-CE, Brasil; renatoleandro.ce@hotmail.com (author for correspondence)

\begin{abstract}
For the simultaneous achievement of productivity in beet and cowpea associations, it is necessary to take into consideration the choice of cultivar combinations that offer a response in terms of production, product quality and efficiency of the intercropping. Thus, the objective of this work was to evaluate the viability of production of beet cultivars combinations with cowpea cultivars in two cropping years (2016 and 2017) in a semi-arid environment. The treatments arranged in a $2 \times 4$ factorial scheme, with four replications, consisted of the combination of two beet cultivars (Early Wonder and Fortuna) with four cowpea cultivars (BRS Tumucumaque, BRS Cauamé, BRS Guariba and BRS Itaim), in addition to monocultures of these cultivars, as an additional treatment. The experimental design used was in randomized complete blocks. The production and its components were evaluated in the beet and cowpea. Apart from these characteristics, the following agro-economic indicators were also determined for each treatment: system productivity index (SPI), the land equivalent coefficient (LEC), and the monetary equivalent ratio (MER). The productive variables of cowpea and of the agroeconomic indicators of the intercropping systems were higher in the second cropping year (2017), while the productive variables of beet were higher in the first cropping year (2016). The Early Wonder and Fortuna cultivars when in intercropping with the cowpea cultivars had similar commercial productivities of roots (11.29 and $\left.11.93 \mathrm{t} \mathrm{ha}^{-1}\right)$, respectively. The cowpea cultivar BRS Tumucumaque $\left(1.38 \mathrm{t} \mathrm{ha}^{-1}\right)$ was the most productive when intercropped with beet. The combinations of cultivars that had the highest agro-economic efficiencies and complementarity were those originated from the associations of BRS Tumucumaque (SPI $=18.43, \mathrm{LEC}=0.52$ and MER $=1.42)$ and BRS Guariba $(\mathrm{SPI}=18.42, \mathrm{LEC}=0.52$ and MER $=1.48$ ) with the Early Wonder beet cultivar.
\end{abstract}

Keywords: Beta vulgaris, Vigna unguiculata, Calotropis procera, crop association, semi-arid environment.

\section{RESUMO}

Eficiência de produção em combinações de cultivares de beterraba e feijão-caupi

Para a obtenção simultânea de alta produtividade, qualidade do produto e eficiência em associações como a de beterraba e feijãocaupi, é necessário levar em consideração a escolha de combinações de cultivares. Assim, o objetivo deste trabalho foi avaliar a viabilidade de produção de combinações de cultivares de beterraba com cultivares de feijão-caupi em dois anos de cultivos (2016 e 2017), em ambiente semiárido. Os tratamentos dispostos em esquema fatorial $2 \times 4$, foram provenientes da combinação de duas cultivares de beterraba (Early Wonder e Fortuna) e quatro de feijão-caupi (BRS Tumucumaque, BRS Cauamé, BRS Guariba e BRS Itaim), além dos monocultivos dessas cultivares, como tratamento adicional. O delineamento experimental usado foi em blocos completos casualizados, com quatro repetições. Foram avaliados a produção e seus componentes da beterraba e no feijão-caupi, além dos indicadores agroeconômicos: índice de produtividade do sistema (IPS), coeficiente equivalente de terra (CET) e razão de equivalência monetária (REM). As variáveis produtivas do feijão-caupi e dos indicadores agroeconômicos dos sistemas consorciados foram mais altas no segundo ano agrícola (2017), enquanto que as variáveis produtivas da beterraba foram maiores no primeiro ano agrícola (2016). As cultivares Early Wonder e Fortuna, quando consorciadas com as cultivares de feijão-caupi, apresentaram produtividades comerciais de raízes similares $(11,29$ e 11,93 $\mathrm{t} \mathrm{ha}^{-1}$, respectivamente). A cultivar de feijão-caupi BRS Tumucumaque foi a mais produtiva $\left(1,38 \mathrm{tha}^{-1}\right)$, quando consorciada com a beterraba. As combinações de cultivares que apresentaram as maiores eficiências agroeconômicas e complementaridade foram aquelas provenientes das associações de BRS Tumucumaque (IPS $=18,43, \mathrm{CET}=0,52$ e REM $=1,42)$ e BRS Guariba $($ IPS $=18,42$, $\mathrm{CET}=0,52$ e $\mathrm{REM}=1,48$ ) com a cultivar de beterraba Early Wonder.

Palavras-chaves: Beta vulgaris, Vigna unguiculata, Calotropis procera, consorciação, semiárido.

\section{Received on December 11, 2019; accepted on October 5, 2020}

$\mathrm{T}^{\mathrm{s}}$ he intercropping of cultures, commonly called the association of crops, can be indicated as a sustainable model of production and consumption in family agriculture. This system is not associated to the use of high technology, or to the obtaining of high yields, being efficient, especially for small producers (Oliveira et al., 2010). The diversification of the system with the association of crops is a way to increase income, reduce risks and uncertainties in rural property. Thus, the association of crops can demonstrate that it is a viable and possible alternative to be introduced in a semi-arid environment, where family farming and small rural properties prevail (Costa et al., 2017). 
Cowpea is a crop that presents a satisfactory productive response when associated with tuberous species such as carrot (Daucus carota) (Favacho et al., 2017), radish (Raphanus sativus) (Pereira et al., 2016) and beet (Beta vulgaris) (Moraes, 2016). This response is due to the better spatial and temporal combination of the two cultures in terms of demand and of the beneficial biological interactions that occur between them, thus optimizing growth factors, such as solar radiation, water and nutrients, and consequently increasing their yields.

In order to obtain high productivity and sustainability in cowpea and beet associations, one must take into account the choice of crop cultivar combinations that provide high response in terms of production, product quality and efficiency of the intercropping system. Often the cultivars when associated do not present the best answers (Silva, 2015), due to the different crop systems modifying the production environment, providing changes in the productive and qualitative behavior of these cultivars, either increasing productivity and precocity, or reducing production rates or lengthening the productive cycle.

In the evaluation of intercropping systems, researchers have developed and proposed indices to express agronomic/ biological and economic efficiency of the viability of these systems. To quantify this efficiency, the system productivity index (SPI) and the land equivalent coefficient (LEC) have been recommended to express this agronomic/biological efficiency of the system while the monetary equivalent ratio (MER) has been suggested to evaluate the economic efficiency. The main advantage of SPI is the standardization of the productivity of the secondary crop (cowpea) in terms of the main crop (beet), as reported by Oseni \& Aliyu (2010). This index also identifies the combination that uses the growth resources more effectively, as well as characterizes the performance of productive stability. LEC values higher than 0.25 and MER values higher than 1 , indicate, respectively, more productive and profitable intercropped systems.

Evaluating combinations of four cowpea cultivars (BRS Itaim, BRS Tumucumaque, BRS Guariba and BRS Cauamé) with two carrot cultivars (Brasília and Alvorada) in a intercropping system in a semi-arid environment, Costa et al. (2017) observed higher yields on the combinations of cowpea cultivar BRS Guariba with the carrot cultivars Brasília and Alvorada, with efficiency of production in the intercropped system around 50 and $65 \%$ in relation to the single crops.

There is no record of research on which cultivars of beet and cowpea are most suitable to the intercropping system in the semi-arid environment of northeastern Brazil. Therefore, the objective of this work was to evaluate the production viability of beet cultivars combinations with cowpea cultivars in two cropping years (2016 and 2017) in a semi-arid environment.

\section{MATERIAL AND METHODS}

\section{Site, climate and experimental procedure}

Two experiments were undertaken from August to October 2016 and from October to December 2017 at the Rafael Fernandes Experimental Farm, located in Lagoinha district, $20 \mathrm{~km}$ far from Mossoró-RN ( $5^{\circ} 03$ 'S, $37^{\circ} 25^{\prime} \mathrm{W}, 72 \mathrm{~m}$ altitude), in soil classified as typical dystrophic Red Argisol (Rêgo et al., 2016). The climate of the region is semi-arid, being classified according to Köppen as BShw', dry and very hot, presenting a rainy season in the summer delaying to the autumn, with $27.4^{\circ} \mathrm{C}$ annual average temperature, irregular annual rainfall, with a mean of 673.9 $\mathrm{mm}$ and $68.9 \%$ relative humidity (Dias et al., 2010). Average temperature and air relative humidity in the days after sowing the beet and cowpea crops during the crop cycles in the two cropping years were $27.5^{\circ} \mathrm{C}$ and $61.5 \%$, and $27.7^{\circ} \mathrm{C}$ and $66.1 \%$ in the years 2016 and 2017 , respectively.

The treatments were arranged in a $2 \times 4$ factorial scheme, in complete randomized blocks experimental design, with four replications, consisting of the combination of two beet cultivars (Early Wonder and Fortuna) with four cowpea cultivars (BRS Tumucumaque, BRS Cauamé, BRS Guariba and BRS Itaim), in addition to the monocultures of these cultivars, as additional treatment in two cropping years (2016 and 2017).

\section{Management and cropping system}

Before the installation of the experiments, the experimental area was prepared by plowing and harrowing, followed by the construction of beds by means of a bed shaper. Subsequently, these beds were manually covered with 30 micron Bril Fles Vulcabrilho transparent plastic film for the solarization of the soil for a period of 35 days in 2016 and 2017 before the first fertilization.

After the removal of the plastics, soil samples were taken from the experimental plots at $0-0.20 \mathrm{~m}$ depth and sent to the Laboratory of Soil Fertility and Chemistry of the Universidade Federal Rural do Semi-Árido (UFERSA), showing the following results. In the first cropping year (2016), $\mathrm{pH}$ (water) = 8.2; in $\mathrm{g} \mathrm{kg}^{-1}, \mathrm{~N}=0.51$, $\mathrm{OM}=3.64$; in $\mathrm{mg} \mathrm{dm}{ }^{-3}, \mathrm{P}=10.30, \mathrm{~K}^{+}=57.20, \mathrm{Na}^{+}=$ 11.60; in $\mathrm{cmol}_{\mathrm{c}} \mathrm{dm}^{-3}, \mathrm{Ca}^{+2}=0.60, \mathrm{Mg}^{+2}$ $=0.58 ; \mathrm{EC}=1.77 \mathrm{ds} \mathrm{m}^{-1}$. In the second growing year (2017): $\mathrm{pH}$ (water) $=6.6$; in $\mathrm{g} \mathrm{kg}^{-1}, \mathrm{~N}=0.42, \mathrm{OM}=3.65$; in $\mathrm{mg}$ $\mathrm{dm}^{-3}, \mathrm{P}=34.20, \mathrm{~K}^{+}=69.20, \mathrm{Na}^{+}=19.00$; in $\mathrm{cmol}_{\mathrm{c}} \mathrm{dm}^{-3}, \mathrm{Ca}^{+2}=3.10, \mathrm{Mg}^{+2}=0.80$; $\mathrm{EC}=1.05 \mathrm{ds} \mathrm{m}^{-1}$.

The intercropping systems were established in alternating strips of four cowpea rows and four rows of beet in the useful area of the plot, with two more border rows of each crop at the ends of the plots forming the experimental plots of each treatment (Figure 1). The total area of the experimental plot of the intercropped cultivation was $3.60 \mathrm{~m}^{2}$ $(3.00 \times 1.20 \mathrm{~m})$ with $2.00 \mathrm{~m}^{2}$ useful area $(2.00 \times 1.00 \mathrm{~m})$, being $50 \%$ of the area cultivated with cowpea and 50\% with beet. The spacing adopted for cowpea and beet was $0.25 \mathrm{~m}$ between crop rows and $0.10 \mathrm{~m}$ and $0.04 \mathrm{~m}$ between crop plants, respectively, totaling 140 plants of cowpea and beet in the useful area of the plot, respectively.

The single crop plots of cowpea had a total area of $3.60 \mathrm{~m}^{2}(3.00 \times 1.20 \mathrm{~m})$, with $2.00 \mathrm{~m}^{2}$ useful area $(2.00 \times 1.00 \mathrm{~m})$, and spacing between rows and plants 
of $0.50 \mathrm{~m} \times 0.10 \mathrm{~m}$. For beet, the total area of the plot was $1.44 \mathrm{~m}^{2}$, with 0.80 $\mathrm{m}^{2}$ useful area with spacings between rows and plants of $0.20 \mathrm{~m} \mathrm{x} 0.10 \mathrm{~m}$. The planting density recommended in the region for cowpea is 200,000 plants per hectare (Santos, 2011), and for beet of 500,000 plants per hectare (Silva et al., 2011). The population densities of both, beet and cowpea, were the same in both cropping systems.

In the experimental plots, Calotropis procera was used for green manuring, collected at properties near the city of Mossoró-RN in the two cropping years. The plants were cut manually with the aid of machete, extracting only the green part of the plant. After collection, the material was ground into approximately 2 to $3 \mathrm{~cm}$ pieces and placed in a plastic canvas exposed to the sun for drying during 4 to 6 days, until approximately $10 \%$ moisture was obtained. During this period the material was revolved twice a day, morning and afternoon, and then bagged, weighed and stored for later incorporation. Prior to incorporation, the chemical compositions of Calotropis procera biomasses were (in $\left.\mathrm{g} \mathrm{kg}^{-1}\right)$ : $\mathrm{N}=$ 18.40; $\mathrm{P}=3.14 ; \mathrm{K}=14.50 ; \mathrm{Ca}=16.30$; $\mathrm{Mg}=13.35$, and a $\mathrm{C} / \mathrm{N}$ ratio of $25 / 1$ in the first cropping year, and (in $\mathrm{g} \mathrm{kg}^{-1}$ ) $\mathrm{N}=21.90 ; \mathrm{P}=1.92 ; \mathrm{K}=25.60 ; \mathrm{Ca}=$ $17.00 ; \mathrm{Mg}=9.22$, and a $\mathrm{C} / \mathrm{N}$ ratio of $25 / 1$ in the second cropping year.

The manuring, both in the intercropping and in the monocropping systems, was carried out in the same way in two stages, with $50 \%$ of the material incorporated 20 days before planting in all plots and the remaining $50 \%$ also incorporated into the soil, 30 days after sowing of the crops, in the amount of $46.84 \mathrm{t} \mathrm{ha}^{-1}$ of $C$. procera according to the methodology of Sousa et al. (2018). This methodology was carried out with the aid of a hoe, making furrows between the planting lines, then, depositing in these furrows the green manure biomass and finally, incorporating with the soil.

Crops were sown simultaneously by no-tillage on August 23, 2016 and October 10, 2017. The replanting and thinning of cowpea and beet crops were carried out at 7 and 10 days and at 11 and 14 days after sowing the crops, on the years 2016 and 2017, respectively.

Survey of cowpea stems in each plot was carried out shortly after the formation of the "pod switchblade". This technique consists of laying pickets between the two crops by the sides and along the beds. This picket must lie close to the first row of cowpea next to the beet, and then tie the end of a string to one of the pickets and pass it under the older leaves of the cowpea, tying the other end into the picket on the opposite side. After raising the stems of the cowpea, twenty plants were randomly marked with a ribbon within the useful area for further post-harvest evaluation.

The area was irrigated by micro sprinkler, in two irrigation shifts, one in the morning and the other in the afternoon. The amount of water supplied was determined by the values of the crop coefficient of cowpea (initial $\mathrm{K}$ $=0.5$, medium $\mathrm{K}_{\mathrm{c}}=1.05$ and final $\mathrm{K}_{\mathrm{c}}$ $=0.90)$, with an irrigation depth, when necessary, between 14 and $16 \mathrm{~mm}$ per day (Lima et al., 2010). Sporadically, around each beet plant, soil was hilled up in order to cover the "shoulder" of the roots against sun exposure. Manual weeding was carried out whenever necessary in the area. Cowpea green pod harvests were performed in the period of 54 to 69 days on 2016 and 55 to 69 days on 2017, in which four harvests were made according to the picking point of the pods. Beet harvests were performed at 71 days after planting in 2016 and 2017, respectively.

\section{Evaluated characteristics and indices}

The characteristics evaluated in the cowpea were: length of green pods, number of pods per square meter, productivity and dry mass of green pods, number of green grains per pod, productivity and dry mass of green grains. In the beet were: plant height, root diameter, fresh and dry mass of shoots, root dry mass, and total and commercial productivity of roots. In the intercrops we evaluated, the system productivity index (SPI), the land equivalent coefficient (LEC) and the monetary equivalent ratio (MER). The system productivity index was obtained by the expression: $\mathrm{SPI}=\left[\left(\mathrm{Y}_{\mathrm{b}} / \mathrm{Y}_{\mathrm{c}}\right) \mathrm{x}\right.$ $\left.\mathrm{Y}_{\mathrm{cb}}\right]+\mathrm{Y}_{\mathrm{bc}}$, where $\mathrm{Y}_{\mathrm{b}}$ and $\mathrm{Y}_{\mathrm{c}}$ represent the productivities of commercial roots of beet and green grains of cowpea in monocultures, $\mathrm{Y}_{\mathrm{cb}}$ the productivity of green grains of cowpea in intercrop with the beet and $\mathrm{Y}_{\mathrm{bc}}$ is the productivity of commercial roots of the beet in intercrop with the cowpea.

The land equivalent coefficient was calculated using the expression LEC $=\operatorname{LER}_{c} \times$ LER $_{b}$. These authors consider an intercrop advantageous when the equivalent coefficient of land obtained is greater than $25 \%$. The equivalent monetary coefficient (MER) was determined by the expression: MER $=\left(\mathrm{GI}_{\mathrm{bc}}+\mathrm{GI}_{\mathrm{cb}}\right) / \mathrm{GI}_{\mathrm{b}}$, where $\mathrm{GI}_{\mathrm{bc}}$ is the gross income of beet in intercrop with cowpea; $\mathrm{GI}_{\mathrm{cb}}$ is the gross income of the cowpea in intercrop with the beet; $\mathrm{GI}_{b}$ is the highest gross income in monoculture of crop $b$ when compared to that of crop $c$. This index measures the economic superiority, or not, of the intercrop over the most economical monoculture.

\section{Statistical analysis}

Univariate analyzes of variances were performed on the characteristics of cowpea and beet and on the efficiency indices of the intercropping system in each cropping year. Subsequently, a joint analysis for the two cropping years was performed on all variables evaluated using the SISVAR software (Ferreira, 2011). The Tukey test was used to compare the means between cowpea cultivars tested, and the F test between beet cultivars, and cropping years and systems.

\section{RESULTS AND DISCUSSION}

\section{Cowpea productive performance}

Interactions were observed between cropping years and cowpea cultivars in intercrop and monocrop in the productivity of green grains (PGG), and between cropping years and cropping systems, and between cropping years and cowpea cultivars in monocrop in the productivity of green pods (PGP) (Table 1). However, for the cowpea cultivars in intercrop within each cropping year we observed that cultivars BRS Tumucumaque, BRS Cauamé and BRS Guariba stood out from BRS Itaim in the first year in the PGG, while in 
the second year there was an inverse behavior, where cultivar BRS Itaim stood out from the others. In monocrop, the cultivar BRS Cauamé stood out from the others only in the first cropping year. These results may be associated with the adaptive capacity of cowpea cultivars to the soil conditions between the first and second crops. In other words, the cultivars BRS Tumucumaque, BRS Cauamé, and BRS Guariba, were better adapted to an alkaline soil, different from that the second crop, where BRS Itaim adapted to an acidic soil.

Conversely, analyzing the cropping years within each cowpea cultivar, the highest PGG were registered in the second cropping year as compared to the first. This difference can be related to the integration between the chemical characteristics of green manure and the $\mathrm{pH}$ of the soil close to the neutrality presented in the second harvest. Thus, the nitrogen $(\mathrm{N})$ decomposition and mineralization processes are influenced by the chemical characteristics of the biomass; especially in the first weeks of decomposition (Radicetti et al., 2017). The organic matter, the product of this process, can make nutrients available to plants during cultivation, especially during the grain filling period. However, it is important to emphasize that the farmer must be aware of the acidity of the soil in case of one or more green manures per year.

The monocropping produced more than the intercropping system in the productivity of green pods at both cropping years. This is probably related to the absence of interspecific competition over the natural resources of the environment. However, in intercropping cultivation, the presence of interspecific competition may, depending on the crops, decrease their respective productivities due to the high competition for soil nutrients and a decrease in the efficiency of plants to the available nutrients (Chaves et al., 2020).

On the other hand, for cropping years within each cropping system, the first year stood out from the second one in the monocropping in the productivity of green pods, while the second one stood out from the first one in the intercropping (Table 1). In the first monocropping year, possibly the practice of incorporating green manure made it possible to reduce soil alkalinity $(\mathrm{pH})$ and optimize nutrient availability for cowpea plants in the formation of green pods. Góes et al. (2014), studying the alterations of the soil fertilized with Merremia aegyptia, found that the $\mathrm{pH}$ of the soil decreased and the levels of N, P, K, Ca and $\mathrm{Mg}$ increased with the amounts of $M$. aegyptia incorporated into the soil. However, despite green manuring, the alkalinity of the soil associated with the presence of interspecific competition, possibly impaired the system of intercropping in the first year. In the second year

\begin{tabular}{|c|c|c|c|c|c|c|c|c|c|c|c|}
\hline \multicolumn{2}{|c|}{ Beet } & \multicolumn{4}{|c|}{ Cowpea } & \multicolumn{2}{|c|}{ Beet } & \multicolumn{3}{|c|}{ Cowpea } & \\
\hline \multirow{12}{*}{ 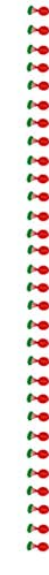 } & $\infty$ & 8 & 8 & 2 & $\therefore \frac{\infty}{2000}$ & $\infty$ & $\therefore$ & $\infty$ & 8 & 8 & \\
\hline & $\therefore$ & 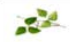 & $x^{2}$ & $8^{2}$ & os & $\therefore$ & 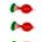 & $\therefore$ & 8 & 8 & \\
\hline & $\infty$ & 8 & $x^{2}$ & $8^{2}$ & 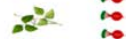 & $\therefore$ & $\infty$ & $\infty$ & 2 & $3^{2}$ & \\
\hline & $\because$ & $\therefore$ & 8 & 8 & 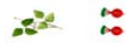 & $\therefore$ & $\therefore$ & $\infty$ & 8 & 8 & \\
\hline & $\infty$ & 3 & 28 & 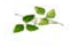 & 87 & $\infty$ & $\infty$ & $\infty$ & 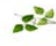 & 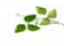 & \\
\hline & $\therefore \overline{8}$ & 8 & 8 & 28 & 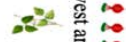 & $\therefore$ & $\therefore$ & $\therefore$ & 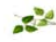 & 3 & $\Xi$ \\
\hline & $\infty^{3}$ & $\therefore$ & $8^{2}$ & $8^{2}$ & $g^{2}$ & $\infty$ & $\infty$ & $\infty$ & 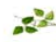 & 8 & \\
\hline & $\infty$ & 8 & 8 & 8 & $8 \%$ & $\approx$ & $\infty$ & $\infty$ & 2 & $\approx$ & \\
\hline & $\infty$ & $3^{2}$ & $3^{2}$ & 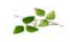 & $\therefore$ & $\infty$ & $\infty$ & $\infty$ & 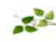 & 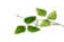 & \\
\hline & $\infty$ & 8 & $3^{2}$ & 28 & $\therefore$ & $\infty$ & $\infty$ & $\infty$ & 8 & 8 & \\
\hline & $\because$ & 3 & 2 & 2 & $8 \%$ & $\approx$ & $\infty$ & 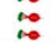 & 2 & \# & \\
\hline & $\approx$ & 8 & 28 & 28 & 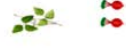 & $\therefore$ & $\therefore$ & $\infty$ & 2 & 8 & \\
\hline & & & & & & & & & & $25 \mathrm{~m}$ & \\
\hline
\end{tabular}

Figure 1. Detail of an experimental plot of the intercropping of beet and cowpea. Mossoró, UFERSA, 2016-2017. of intercropped cultivation, the soil with $\mathrm{pH}$ 6.60, supposedly favored the availability of nutrients for the cowpea plants in the formation of green pods.

Comparing the cowpea cultivars in monocrop within each cropping year, the cultivar BRS Cauamé stood out from the others in the productivity of green pods in the first cropping year (Table 1). Conversely, this productivity of pods did not differ in the second cropping year.

The cultivars BRS Tumucumaque and BRS Cauamé both in intercrop and monocrop stood out from the others in the length of green pods, whereas only the cultivar BRS Guariba excelled the others in the number of green grains per pod (Table 1). For the productivity of green pods in intercrop only the cultivar BRS Tumucumaque stood out from the others. No significant differences were observed in the characteristics evaluated in the cowpea between beet cultivars tested.

Significant differences were registered between mean values of green pod length and number of green grains per pod in the cropping years, with the second year differing from first year. For the cropping systems, these same characteristics together with productivity of green grains had the highest mean values in monocropping (Table 1).

Selection of cultivar combinations for the performance improvement of the intercropping systems is dependent on the objectives of the cropping system. Farmers who intercrop a tuberous crop with cowpea generally practice this cropping system to stabilize crop yields, reduce the risk of crop failure due to some irregularities in the weather or in other factors, and to spread the peaks of labor (Costa et al., 2017). They usually seek to obtain a total yield of roots with some additional grains and cowpea forage. Research in northeastern Brazil with commercial cultivars of tuberous cultures and cowpea is increasingly directed towards the effort to maintain the inherent stability of traditional cropping systems as the intercropping one and at the same time increase productivity.

The productivities of green pods and grains of the cowpea semi-erect cultivars 
Table 1. Mean values for length of green pods (LGP), productivity of green pods (PGP), number of green grains per pod (NGGP) and productivity of green grains (PGG) of cowpea cultivars in intercrop and monocrop, with beet cultivars in intercrop at two cropping years and cropping systems. Mossoró, UFERSA, 2016-2017.

\begin{tabular}{|c|c|c|c|c|c|c|}
\hline \multirow{2}{*}{ Cowpea cultivars in intercrop } & \multirow{2}{*}{ LGP (cm) } & \multirow{2}{*}{\multicolumn{2}{|c|}{$\operatorname{PGP}\left(\mathrm{t} \mathrm{ha}^{-1}\right)$}} & \multirow{2}{*}{ NGGP } & \multicolumn{2}{|c|}{ PGG $\left(\right.$ t ha $\left.^{-1}\right)$} \\
\hline & & & & & Year 2016 & Year 2017 \\
\hline BRS Tumucumaque & $20.10 \mathrm{~A}$ & \multicolumn{2}{|c|}{$2.04 \mathrm{~A}$} & $9.03 \mathrm{~B}$ & $0.81 \mathrm{bA}$ & $1.94 \mathrm{aB}$ \\
\hline BRS Cauamé & $20.51 \mathrm{~A}$ & \multicolumn{2}{|c|}{$1.72 \mathrm{~B}$} & 9.34B & $0.60 \mathrm{bA}$ & $1.95 \mathrm{aB}$ \\
\hline BRS Guariba & $18.71 \mathrm{~B}$ & \multirow{2}{*}{\multicolumn{2}{|c|}{$\begin{array}{l}1.63 \mathrm{~B} \\
1.18 \mathrm{C}\end{array}$}} & $11.26 \mathrm{~A}$ & $0.72 \mathrm{bA}$ & $1.67 \mathrm{aB}$ \\
\hline BRS Itaim & $15.74 \mathrm{C}$ & & & $7.62 \mathrm{C}$ & $0.16 \mathrm{bB}$ & $2.41 \mathrm{aA}$ \\
\hline \multicolumn{7}{|l|}{ Beet cultivars in intercrop } \\
\hline Early Wonder & $18.46 \mathrm{~A}$ & \multicolumn{2}{|c|}{$1.51 \mathrm{~A}$} & $9.09 \mathrm{~A}$ & \multicolumn{2}{|c|}{$1.26 \mathrm{~A}$} \\
\hline Fortuna & $19.07 \mathrm{~A}$ & \multicolumn{2}{|c|}{$1.77 \mathrm{~A}$} & $9.53 \mathrm{~A}$ & \multicolumn{2}{|c|}{$1.30 \mathrm{~A}$} \\
\hline \multicolumn{7}{|l|}{ Cropping years } \\
\hline 2016 & $18.56 \mathrm{~B}$ & \multicolumn{2}{|c|}{$2.26 \mathrm{~B}$} & $9.31 \mathrm{~B}$ & \multicolumn{2}{|c|}{$0.98 \mathrm{~B}$} \\
\hline 2017 & $19.64 \mathrm{~A}$ & \multicolumn{2}{|c|}{$2.42 \mathrm{~A}$} & $10.24 \mathrm{~A}$ & \multicolumn{2}{|c|}{$2.57 \mathrm{~A}$} \\
\hline Cropping systems & & Year 2016 & Year 2017 & & & \\
\hline Intercropping & $18.77 \mathrm{~B}$ & $1.33 \mathrm{bB}$ & $1.95 \mathrm{aB} *$ & $9.31 \mathrm{~B}$ & \multicolumn{2}{|c|}{$1.28 \mathrm{~B}$} \\
\hline Monocropping & $19.78 \mathrm{~A}$ & $4.15 \mathrm{aA}$ & $3.36 \mathrm{bA}$ & $10.72 \mathrm{~A}$ & \multicolumn{2}{|c|}{$2.74 \mathrm{~A}$} \\
\hline Cowpea cultivars in monocrop & & & & & Year 2016 & Year 2017 \\
\hline BRS Tumucumaque & $21.10 \mathrm{~A}$ & $3.48 \mathrm{aB}$ & $3.76 \mathrm{aA}$ & $10.40 \mathrm{~B}$ & $1.55 \mathrm{bB}$ & $3.81 \mathrm{aA}$ \\
\hline BRS Cauamé & $21.31 \mathrm{~A}$ & $6.37 \mathrm{aA}$ & $3.28 \mathrm{bA}$ & $10.77 \mathrm{~B}$ & $2.75 \mathrm{aA}$ & $3.43 \mathrm{aA}$ \\
\hline BRS Guariba & $19.84 \mathrm{~B}$ & $3.75 \mathrm{aB}$ & $3.39 \mathrm{aA}$ & $12.87 \mathrm{~A}$ & $1.63 \mathrm{bB}$ & $3.94 \mathrm{aA}$ \\
\hline BRS Itaim & $16.86 \mathrm{C}$ & $2.98 \mathrm{aB}$ & $3.01 \mathrm{aA}$ & $8.81 \mathrm{C}$ & $1.28 \mathrm{bB}$ & $3.54 \mathrm{aA}$ \\
\hline
\end{tabular}

*Means followed by the same lowercase letter in the line and capital letter in the column do not differ by F (Cropping years, Cropping systems and Beet cultivars in intercrop) or Tukey (cowpea cultivars in intercrop and monocrop) test at $5 \%$ probability level.

Table 2. Fresh mass of the shoots (FMS), productivity of total (PTR) and commercial roots (PCR), and root diameter (RD) of beet cultivars in intercrop and monocrop, with cowpea cultivars in intercrop at two cropping years and cropping systems. Mossoró, UFERSA, $2016-2017$.

\begin{tabular}{|c|c|c|c|c|c|c|}
\hline Cowpea cultivars in intercrop & FMS (t ha-1) & \multicolumn{2}{|c|}{ PTR $\left(\mathrm{t} \mathrm{ha}^{-1}\right)$} & \multicolumn{2}{|c|}{ PCR $\left(t\right.$ ha $\left.^{-1}\right)$} & RD (cm) \\
\hline BRS Tumucumaque & $23.29 \mathrm{~A}$ & \multicolumn{2}{|c|}{ 14.19A } & \multicolumn{2}{|c|}{$11.81 \mathrm{~A}$} & $4.91 \mathrm{~A}$ \\
\hline BRS Cauamé & $22.08 \mathrm{~A}$ & \multicolumn{2}{|c|}{$13.33 \mathrm{~A}$} & \multicolumn{2}{|c|}{$11.13 \mathrm{~A}$} & $4.79 \mathrm{~A}$ \\
\hline BRS Guariba & $22.38 \mathrm{~A}$ & \multicolumn{2}{|c|}{$14.92 \mathrm{~A}$} & \multicolumn{2}{|c|}{$12.64 \mathrm{~A}$} & $4.89 \mathrm{~A}$ \\
\hline BRS Itaim & $21.15 \mathrm{~A}$ & \multicolumn{2}{|c|}{$13.41 \mathrm{~A}$} & \multicolumn{2}{|c|}{$10.87 \mathrm{~A}$} & $4.71 \mathrm{~A}$ \\
\hline \multicolumn{7}{|l|}{ Beet cultivars in intercrop } \\
\hline Early Wonder & $27.36 \mathrm{~A}$ & \multicolumn{2}{|c|}{$13.81 \mathrm{~A}$} & \multicolumn{2}{|c|}{$11.29 \mathrm{~A}$} & $4.80 \mathrm{~A}$ \\
\hline Fortuna & 17.09B & \multicolumn{2}{|c|}{$14.12 \mathrm{~A}$} & \multicolumn{2}{|c|}{$11.93 \mathrm{~A}$} & $4.86 \mathrm{~A}$ \\
\hline \multicolumn{7}{|l|}{ Cropping years } \\
\hline 2016 & $21.31 \mathrm{~B}$ & \multicolumn{2}{|c|}{$14.96 \mathrm{~A}$} & \multicolumn{2}{|c|}{$13.09 \mathrm{~A}$} & $5.28 \mathrm{~A}$ \\
\hline 2017 & $23.73 \mathrm{~A}$ & \multicolumn{2}{|c|}{$13.48 \mathrm{~B}$} & \multicolumn{2}{|c|}{$11.07 \mathrm{~B}$} & $4.58 \mathrm{~B}$ \\
\hline Cropping systems & & Year 2016 & Year 2017 & Year 2016 & Year 2017 & \\
\hline Intercropping & $22.23 \mathrm{~A}$ & $13.67 \mathrm{aB} *$ & $14.26 \mathrm{aA}$ & $11.79 \mathrm{aB}$ & $11.44 \mathrm{aA}$ & $4.83 \mathrm{~B}$ \\
\hline Monocropping & $23.70 \mathrm{~A}$ & $20.11 \mathrm{aA}$ & $10.38 \mathrm{bB}$ & $18.32 \mathrm{aA}$ & $9.58 \mathrm{bA}$ & $5.32 \mathrm{~A}$ \\
\hline \multicolumn{7}{|l|}{ Beet in monocrop } \\
\hline Early Wonder & $29.52 \mathrm{~A}$ & $22.65 \mathrm{aA}$ & $9.88 \mathrm{bA}$ & 14. & & $5.31 \mathrm{~A}$ \\
\hline Fortuna & $17.89 \mathrm{~B}$ & $17.57 \mathrm{aB}$ & $10.89 \mathrm{bA}$ & 13. & & $5.34 \mathrm{~A}$ \\
\hline
\end{tabular}

*Means followed by the same lowercase letter in the line and capital letter in the column do not differ by F (cropping years, cropping systems and beet cultivars in intercrop) or Tukey (cowpea cultivars in intercrop) test at the 5\% probability level. 
BRS Tumucumaque, BRS Cauamé and BRS Guariba and erect cultivar BRS Itaim in intercrop compared to monocrop were: 54.3 and 51.1; 35.6 and $41.1 ; 45.6$ and 43.0 ; and 34.5 and $53.1 \%$. As can be observed, the semierect materials when intercropped had a good productive performance, especially the BRS Tumucumaque and BRS Guariba cowpea cultivars. The intercropped system, on average, produced approximately 43.7 and $46.7 \%$ of the productivities of green pods and grains obtained in monocropped system.

The green pod lengths of BRS Tumucumaque $(20.10 \mathrm{~cm})$ and BRS Cauamé $(20.51 \mathrm{~cm})$ cowpea cultivars obtained in intercropping were very close to those registered with these cowpea cultivars $(21.10$ and $21.31 \mathrm{~cm})$ in monocropping (Table 1). On the other hand, the mean number of green grains per pod registered in the BRS Guariba cowpea cultivar (11.26 grains) in intercropping was also very close to that obtained in this cowpea cultivar (12.87 grains) in monocropping. These results disagree of those mean values obtained by Costa et al. (2017) with BRS Guariba in intercropping (6.78 grains) and in monocropping (10.02 grains) cultivated at the same semi-arid environment of this research.

\section{Beet productive performance}

Interactions were observed between cropping years and cropping systems for the total and commercial productivities of roots, and between cropping years and beet cultivars in monocrop in the total productivity of beet roots (Table 2 ). However, in the intercropping system, the total and commercial productivities were similar in both cropping years, while in the monocropping system these productivities were higher in the first cropping year. This result shows that this system performed better in the first year, due to environmental conditions, chemical composition of the soil and the quality of the incorporated green manure.

No significant difference between cropping systems was registered in the second cropping year in the commercial productivity of beet roots. However, opposite behavior was recorded on both, total and commercial productivity of roots, in the first cropping year, where the monocropping system stood out from the intercropping. In the second year, the total productivity of beet roots in the intercropping stood out from that of monocropping. This result shows that the intercropping system efficiently managed the use of natural resources, compared to monocropping system, due to a greater complementarity of the cultures involved, resulting in a productive gain per hectare.

Conversely, analyzing the beet cultivars in monocrop within each cropping year, Early Wonder cultivar had higher total productivity of roots

Table 3. Mean values for system productive index (SPI), land equivalent coefficient (LEC), and monetary equivalent ratio (MER) of cowpea intercropped with beet at two cropping years, in the different combinations of cowpea and beet cultivars. Mossoró, UFERSA, $2016-2017$.

\begin{tabular}{|c|c|c|c|c|c|}
\hline Cropping years & \multicolumn{2}{|c|}{ SPI } & LEC & \multicolumn{2}{|c|}{ MER } \\
\hline 2016 & \multicolumn{2}{|c|}{$18.11 \mathrm{~A}$} & $0.23 \mathrm{~B}$ & \multicolumn{2}{|c|}{$0.78 \mathrm{~B}$} \\
\hline 2017 & \multicolumn{2}{|c|}{$16.82 \mathrm{~A}$} & $0.70 \mathrm{~A}$ & \multicolumn{2}{|c|}{$1.97 \mathrm{~A}$} \\
\hline Beet cultivars in intercrop & Year 2016 & Year 2017 & & Year 2016 & Year 2017 \\
\hline Early Wonder & $19.48 \mathrm{aA}$ & $15.17 \mathrm{bB} *$ & $0.47 \mathrm{~A}$ & $0.68 \mathrm{bA}$ & $2.14 \mathrm{aA}$ \\
\hline Fortuna & $16.74 \mathrm{bB}$ & $18.47 \mathrm{aA}$ & $0.46 \mathrm{~A}$ & $0.88 \mathrm{bA}$ & $1.80 \mathrm{aB}$ \\
\hline \multicolumn{6}{|l|}{ Cowpea cultivars in intercrop } \\
\hline BRS Tumucumaque & \multicolumn{2}{|c|}{$18.10 \mathrm{~A}$} & $0.52 \mathrm{~A}$ & \multicolumn{2}{|c|}{$1.41 \mathrm{~A}$} \\
\hline BRS Cauamé & \multicolumn{2}{|c|}{$18.32 \mathrm{~A}$} & $0.46 \mathrm{~A}$ & \multicolumn{2}{|c|}{$1.31 \mathrm{~A}$} \\
\hline BRS Guariba & \multicolumn{2}{|c|}{$18.35 \mathrm{~A}$} & $0.49 \mathrm{~A}$ & \multicolumn{2}{|c|}{$1.44 \mathrm{~A}$} \\
\hline BRS Itaim & \multicolumn{2}{|c|}{$15.10 \mathrm{~A}$} & $0.40 \mathrm{~A}$ & \multicolumn{2}{|c|}{$1.34 \mathrm{~A}$} \\
\hline \multicolumn{6}{|l|}{ Cultivar combinations } \\
\hline BRS Tumucumaque x Early Wonder & \multicolumn{2}{|c|}{18.43} & 0.52 & \multicolumn{2}{|c|}{1.42} \\
\hline BRS Tumucumaque x Fortuna & \multicolumn{2}{|c|}{18.07} & 0.51 & \multicolumn{2}{|c|}{1.40} \\
\hline BRS Cauamé x Early Wonder & \multicolumn{2}{|c|}{18.25} & 0.45 & \multicolumn{2}{|c|}{1.36} \\
\hline BRS Cauamé x Fortuna & \multicolumn{2}{|c|}{18.40} & 0.48 & \multicolumn{2}{|c|}{1.27} \\
\hline BRS Guariba x Early Wonder & \multicolumn{2}{|c|}{18.42} & 0.52 & \multicolumn{2}{|c|}{1.48} \\
\hline BRS Guariba x Fortuna & \multicolumn{2}{|c|}{18.18} & 0.45 & \multicolumn{2}{|c|}{1.41} \\
\hline BRS Itaim x Early Wonder & \multicolumn{2}{|c|}{15.01} & 0.41 & \multicolumn{2}{|c|}{1.40} \\
\hline BRS Itaim x Fortuna & \multicolumn{2}{|c|}{15.20} & 0.39 & \multicolumn{2}{|c|}{1.27} \\
\hline
\end{tabular}

* Means followed by the same capital letter in the column do not differ by F (cropping years, beet cultivars in intercrop) or Tukey (cowpea cultivars in intercrop) test at the $5 \%$ probability level. 
than 'Fortuna' in the first cropping year, and productivity similar to Fortuna in the second year (Table 2). This behavior may be associated with a greater adaptability of the Early Wonder cultivar in the face of environmental conditions, as well as the competitive behavior towards the different cowpea cultivars used.

No significant difference between cowpea cultivars in intercrop was recorded in the fresh mass of shoots, productivities of total and commercial roots, and root diameter (Table 2). Likewise, there was no significant difference between beet cultivars in intercrop in these last three mentioned characteristics. Significant differences between beet cultivars were recorded only on fresh mass of shoots, with Early Wonder standing out from Fortuna. This situation may be related to the growth morphological behavior of cowpea cultivars over beet cultivars. Some beneficial factors that could have influenced on the Early Wonder beet would be lower shading and a greater availability of nutrients, resulting in a gain of fresh mass of the shoots.

The beet plants had higher fresh mass of shoots in the second cropping year when compared to the first year, while in the first cropping year higher productivities of total and commercial roots were recorded, and beet root diameter when compared to those of the second cropping year (Table 2). The behavior of the three last characteristics may be related to the environmental conditions the plants were exposed to, mainly, at the end of the first cropping year, where the plants supposedly reached a balance in the translocation of photoassimilates and their conversion, not only into productive variables, but also into growth characteristics.

No significant difference was recorded between beet cultivars in monocrop in the productivity of commercial roots and root diameter (Table 2). Significant differences between beet cultivars in this system were observed only in the fresh mass of shoots, with Early Wonder cultivar standing out from Fortuna.

It is known that the success of the intercropping system is based on the management of the interactions among the component cultures in order to optimize the growth and productivity of the intercropping system and obtain possible monetary returns, thanks to the effective use of the various inputs compared with the monocropping (Takim, 2012; Chandra et al., 2013; Aminifar \& Ghanbari, 2014).

In this research, high percentages were recorded in the productivities of total and commercial roots of beet cultivars when in intercropping with cowpea regarding to their monocropping. The percentages for these productivities of the Early Wonder and Fortuna cultivars were of 84.9 and $99.2 \%$, and 78.4 and $88.3 \%$ of their monocrops. The intercropping systems originated of the cultivar combinations of beet and of cowpea tested, on average, recorded percentage of 91.52 and $83.2 \%$ in relation to the monocropping, with detach for some combinations that had the cultivar Early Wonder (Table 2).

As can be observed, the beet was the main culture and cowpea was the secondary one. The interactions that occurred between the beet and cowpea cultivars combined confirm the complexity of inter and intraspecific competition types among the plants of the species in intercropping, and their impact on crop yields.

The competition in crop association is double compared to the competition when the crops are in monocropping, that is, competition is of inter- and intraspecific type. Thus, the success of an intercrop will depend on the selection of the combination of tested cultivars and the appropriate management of other factors of production such as fertilization, plant population or spatial arrangements.

The fresh mass of shoots, productivity of commercial roots and root diameter of the Early Wonder cultivar had mean values very close to those of its monocropping, evidencing this material as more suitable to the system intercropped with cowpea.

Agro-economic performance of cowpea-beet cultivar combinations

Interactions were observed between cropping years and beet cultivars in intercrop in the system productivity index and in the monetary equivalent ratio (Table 3 ). The Early Wonder cultivar stood out from Fortuna in the first cropping year in the system productivity index and in the second year in the monetary equivalent ratio. Cultivar Fortuna stood out from Early Wonder in the second cropping year in the system productivity index. No significant difference between beet cultivars was recorded in the monetary equivalent ratio in the first cropping year (Table 3 ).

There was also no significant difference among cowpea cultivars tested in the agro-economic indices evaluated. In the land equivalent coefficient, there was a significant difference between the cropping years, with the second year standing out from the first year. No significant difference was observed between the values of this agronomic index and the beet cultivars (Table 3).

Analyzing the results of the agronomic and monetary indices in the different combinations of cultivars tested, higher values of these indices can be observed in the cultivar combinations of BRS Tumucumaque and Early Wonder and BRS Guariba and Early Wonder. These materials were the ones that presented the best compatibility when in association (Table 3 ).

The main advantage of the intercropping is the more efficient use of available resources in the crop mixture and increased productivity compared to the cultures in monocropping (Lithourgidis et al., 2011). An alternative in the evaluation of the yield advantages of the intercropping is the use of production units, monetary units or nutritional values that can be equally applied to component cultures.

The yield advantage occurs because growth resources, such as light, water and nutrients, are absorbed and converted more completely by the intercropping over time and space as a result of differences in the competitive capacity of growth resources between the component cultures, which explore the variation of mixed crops in characteristics such 
as crown development rates, crown size (width and height), photosynthetic adaptation of canopies to irradiance conditions and depth of rooting (Morris \& Garrity, 1993).

The combinations of the cultivars to be used in intercrop should improve the complementary effects between crops. In addition, in order to obtain advantages in intercrops with combinations of materials, it is important to determine species or cultivars, fertilization, spatial geometry and planting density of the component crops to be used in intercrop, as it is known that several factors can affect the growth of the species used in intercropping, including selection of cultivars, sowing rates and competition between the components of the intercropping (Batista et al., 2016; Costa et al., 2017).

The combinations that presented the highest system productivity index were those where the cultivar BRS Tumucumaque was intercropped with the cultivar Early Wonder and the cultivar BRS Guariba was associated with cultivar Early Wonder. The system productivity index standardizes cowpea crop productivity in terms of the main crop (beet), evidencing a better use of environmental resources when compared to their monocrops. The main advantage of this indice is the standardization of the productivity of the secondary crop (cowpea) in terms of the main crop (beet), as reported by Oseni \& Aliyu (2010). This index also identifies the combination that uses the growth resources more effectively, as well as characterizes the performance of productive stability.

All combinations of cowpea and beet cultivars tested had a LEC higher than 0.25 , indicating a productive advantage or competitive complementarity in the productivity of the intercropped system. This indice evaluates the interspecific interaction between the component cultures and it was such that it provided an advantage in the yield of the intercropped systems of cowpea and beet. The highest LEC values obtained were with the combinations of cultivars BRS Tumucumaque and Early Wonder and BRS Guariba and Early Wonder.

In the intercropping systems, it is important to know the economic value of the system and the profit it can give producers. The monetary equivalent ratio is an indicator of economic feasibility of the intercropped systems and shows if they are advantageous (Chaves et al., 2020). In this study, monetary equivalent ratio values were higher than 1, evidencing monetary advantage of the intercrops coming from cowpea and beet cultivar combinations in relation to their best monocrops, indicating that the intercropped system with the best use of growth resources can translate into economic advantage. The monetary equivalent ratio values in this study varied from $27 \%$ to $48 \%$, reaching their maximum monetary values in the cultivar combinations BRS Tumucumaque and Early Wonder and BRS Guariba and Early Wonder.

The productive variables of cowpea and the agro-economic indicators of the intercropping system were higher in the second cropping year (2017), while the productive variables of beet were higher in the first cropping year (2016). The Early Wonder and Fortuna cultivars when in intercropping with the cowpea cultivars had similar commercial productivities of roots (11.29 and 11.93 t ha $^{-1}$ ), respectively. The cowpea cultivar BRS Tumucumaque (1.38 $\left.\mathrm{t} \mathrm{ha}^{-1}\right)$ was the most productive when intercropped with beet. The combinations of cultivars that had the highest agro-economic efficiencies and complementarity were those originated from the associations of BRS Tumucumaque (SPI $=18.43$, $\mathrm{LEC}=0.52$ and $\mathrm{MER}=1.42$ ) and $\mathrm{BRS}$ Guariba (SPI $=18.42$, LEC $=0.52$ and MER $=1.48)$ with the Early Wonder beet cultivar.

\section{ACKNOWLEDGEMENTS}

Special thanks are due to the Conselho Nacional de Desenvolvimento Cientifico e Tecnológico for their financial support of this work, and to the research group at the Department of Agronomic and Forest Sciences of the Universidade Federal Rural do SemiÁrido, which develops technologies for growing of food crops on family farms.

\section{REFERENCES}

AMINIFAR, J; GHANBARI, A. 2014. Biological facilitative interactions and their roles on maximize growth and productivity of crops in intercropping systems. Scientia Agriculturae 2: $90-95$.

BATISTA, TMV; BEZERRA NETO, F; PORTO, VCN; BARROS JÚNIOR, AP; SILVA, IN; SILVA, ML; LIMA, JSS; OLIVEIRA, EQ. 2016. Bio-agro-economic returns from carrot and salad rocket as intercrops using hairy woodrose as green manure in a semi-arid region of Brazil. Ecological Indicators 67: 458-465

CHANDRA, A; KANDARI, LS; NEGI, VS; MAIKHURI, RK; RAO, KS. 2013. Role of intercropping on production and land use efficiency in the central Himalaya. India, Environment \& We International Journal of Science \& Technology 8: 105-113.

CHAVES, AP; BEZERRA NETO, F; LIMA, JSS; SILVA, JN; NUNES, RLC; BARROS JUNIOR, AP; LIMA, GKL; SANTOS, EC. 2020. Cowpea and beet intercropping agroeconomic dynamics under spatial arrangement and cowpea population density. Horticultura Brasileira 38: 192-203.

COSTA, AP; BEZERRA NETO, F; SILVA, ML; LIMA, JSS; BARROS JÚNIOR, AP; PORTO, VCN. 2017. Intercropping of carrot $\mathrm{x}$ cowpea-vegetables: evaluation of cultivar combinations fertilized with roostertree. Revista Caatinga 30: 633-641.

DIAS, NS; LIRA, RB; BRITO RF; SOUSANETO, ON; FERREIRA NETO, M; OLIVEIRA, AM. 2010. Produção de melão rendilhado em sistema hidropônico com rejeito da dessalinização de água em solução nutritiva. Revista Brasileira de Engenharia Agricola e Ambiental 14: 755-761.

FAVACHO, FS; LIMA, JSS, BEZERRA NETO, F; SILVA, JN; BARROS JÚNIOR, AP. 2017. Eficiência produtiva e econômica do consórcio de cenoura $x$ caupi proveniente de adubação verde e arranjos espaciais. Revista Ciência Agronômica 48: 337-346.

FERREIRA, DF. 2011. Sisvar: a computer statistical analysis system. Ciência $e$ Agrotecnologia 35: 1039-1042.

GÓES, SB; SÁ, JR; DUDA, GP; BEZERRA NETO, F; SILVA, ML; LINHARES, PCF. 2014. Changes in the $\mathrm{pH}$ and macronutrients in soil fertilized with hairy woodrose in different amounts and times of incorporation. Revista Caatinga 27: 1-10.

LIMA, JSS; BEZERRA NETO, F; NEGREIRO, MZ; RIBEIRO, MCC; BARROS JÚNIOR, A. 2010. Productive performance of carrot and rocket cultivars in strip-intercropping system and sole crops. Revista Agrociência 44: 561-574.

LITHOURGIDIS, AS; DORDAS, CA.; DAMALAS, CA; VLACHOSTERGIOS, DN. 2011. Annual intercrops: an alternative pathway for sustainable Agriculture. Australian Journal of Crop Science 5: 396-410.

MORAES, EC. 2016. Viabilidade do consórcio de beterraba e caupi-hortaliça sob adubação 
com flor-de-seda e arranjos espaciais Mossoró: UFERSA. 78p. (M.Sc. dissertation).

MORRIS, RA; GARRITY, DP. 1993. Resource capture and utilization in intercropping-water. Field Crops Research 34: 303-317.

OLIVEIRA, EQ; SOUZA, RJ; CRUZ, MCM; MARQUES, ACF. 2010. Produtividade de alface e rúcula em sistema consorciado, sob adubação orgânica e mineral. Horticultura Brasileira 28: 36-40.

OSENI, TO; ALIYU, IG. 2010. Effect of row arrangements on sorghum-cowpea intercrops in the semi-arid savannah of Nigeria. International Journal of Agriculture and Biology 12: 137-140.

PEREIRA, MFS; BEZERRA NETO, F; PONTES, FST; LINHARES, PCF; SILVA, ML; SILVA, IN. 2016. Productive performance of cowpearadish intercropping under different amounts of rooster tree biomass incorporated into the soil. Revista Brasileira de Engenharia Agricola e Ambiental 20: 965-971.

RADICETTI, E; CAMPIGLIA, E; MARUCCI, A; MANCINELLI, R. 2017. How winter cover crops and tillage intensities affect nitrogen availability in eggplant. Nutrient Cycling in Agroecosystems 108: 177-194.

RÊGO, LGS; MARTINS, CM; SILVA, EF; SILVA, JJA; LIMA, RNS. 2016. Pedogenesis and soil classification of an experimental farm in Mossoró, state of Rio Grande do Norte, Brazil. Revista Caatinga 29: 1036-1042.

SANTOS, CAF. 2011. Cultivares de feijão-caupi para o Vale do São Francisco. Petrolina: Embrapa Semiárido. 10p. (Circular Técnico, 94).

SILVA, FC. 2015. Interação de genótipos com ambientes para qualidade de grãos carioca $\mathrm{e}$ caracteres agronômicos em feijoeiro-comum. Goiânia: UFG. 194p. (M.Sc. dissertation).

SILVA, ML; BEZERRA NETO, F; LINHARES, PCF; SÁ, JR; LIMA, JSS; BARROS JÚNIOR, AP. 2011._Produção de beterraba fertilizada com jitirana em diferentes doses e tempos de incorporação ao solo. Revista Brasileira de Engenharia Agricola e Ambiental 15: 801-809.

SOUSA, DM; BEZERRA NETO F; LIMA JSS; LIMA GKL; CHAVES AP; SILVA JN; 2018. Agro-economic performance of the association of beet with green cowpea in different amounts of hairy woodrose. Revista Brasileira de Engenharia Agricola e Ambiental 22: 194-199.

TAKIM, FO. 2012. Advantages of maize-cowpea intercropping over sole cropping through competition indices. Journal of Agriculture and Biodiversity Research 1: 53-59. 